\title{
Profiling of antioxidant potential and phytoconstituents of Plantago coronopus
}

\author{
C. G. Pereira ${ }^{a}$, L. Custódio ${ }^{a}$, M. J. Rodrigues ${ }^{a}$, N. R. Neng ${ }^{b}$, J. M. F. Nogueira ${ }^{b}$, J. Carlier ${ }^{\text {, }}$ \\ M. C. Costa ${ }^{a}, J$. Varela ${ }^{a}$ and L. Barreira ${ }^{a *}$ \\ ${ }^{\mathrm{a} C e n t r e ~ o f ~ M a r i n e ~ S c i e n c e s ~-~ C C M A R, ~ F a c u l t y ~ o f ~ S c i e n c e s ~ a n d ~ T e c h n o l o g y, ~ U n i v e r s i t y ~ o f ~ A l g a r v e ~-~ U A l g, ~}$ \\ Ed. 7, Campus of Gambelas, 8005-139, Faro, Portugal \\ 'Departamento de Química e Bioquímica - DQB, Faculdade de Ciências - FC, Universidade de Lisboa - UL, \\ Campo Grande, Ed. C8, $5^{\circ}$ piso, 1749-016, Lisboa, Portugal \\ *e-mail: lbarreir@ualg.pt
}

Received: February 23, 2016 - Accepted: May 12, 2016 - Distributed: August 31, 2017

\begin{abstract}
The halophyte species Plantago coronopus has several described ethnomedicinal uses, but few reported biological activities. This work carried out for the first time a comparative analysis of $P$. coronopus organs in terms of phenolic composition and antioxidant activity of organic and water extracts from roots, leaves and flowers. The leaves contents in selected nutrients, namely amino acids and minerals, are also described. Roots (ethyl acetate and methanol extracts) had the highest radical scavenging activity (RSA) towards 1,1-diphenyl-2-picrylhydrazyl (DPPH) and 2,2'-azino-bis(3-ethylbenzothiazoline-6-sulfonic acid) (ABTS) radicals, while leaves (hexane extract) had higher RSA on nitric oxide radical and iron chelating ability. High performance liquid chromatography (HPLC) analysis identified eighteen phenolics from which salicylic acid and epicatechin are here firstly described in Plantago species. Leaves had mineral levels similar to those of most vegetables, proving to be a good source for elements like calcium, sodium, iron and magnesium, and also for several of the essential amino acids justifying it use as food. Our results, especially those regarding the phenolics composition, can explain the main traditional uses given to this plantain and, altogether, emphasize the potential of $P$. coronopus as a source of bioactive molecules particularly useful for the prevention of oxidative stress-related diseases.
\end{abstract}

Keywords: Plantago coronopus, halophytes, phytoconstituents, phenolics, antioxidant activity.

\section{Avaliação do potencial antioxidante e perfil fitoquímico do Plantago coronopus}

\section{Resumo}

A espécie halófita Plantago coronopus tem vários usos etnomedicinais já descritos, mas em relação à bioatividade a informação é escassa. Este trabalho efetuou, pela primeira vez, uma análise comparativa dos órgãos de $P$. coronopus em termos de compostos fenólicos e atividade antioxidante de extratos orgânicos e aquosos provenientes das raízes, folhas e flores da planta, bem como o conteúdo de determinados nutrientes, aminoácidos e minerais, nas folhas da planta. As raízes (extratos de acetato de etila e metanol) apresentaram a maior atividade de captação para os radicais 1,1-difenil-2-picril hidrazil (DPPH) e 2,2'-azino-bis(3-etilbenzotiazolina-6-ácido sulfónico) (ABTS), enquanto as folhas (extrato de hexano) mostraram maior atividade captadora para o radical óxido nítrico bem como maior capacidade quelante do ferro. A análise por cromatografia liquida de alta eficiência (CLAE) identificou dezoito compostos fenólicos e, destes, o ácido salicílico e a epicatequina são aqui descritos pela primeira vez em espécies de Plantago. As folhas desta planta halófita mostraram ainda conter minerais em níveis semelhantes aos da maioria dos vegetais, provando ser uma boa fonte de elementos como o cálcio, sódio, ferro e magnésio, bem como de vários dos aminoácidos essenciais o que justifica seu uso na alimentação. Os resultados, particularmente aqueles relacionados à composição fenólica, podem justificar os principais usos medicinais atribuídos a esta espécie e, na sua totalidade, demonstram o potencial de P. coronopus como fonte de moléculas bioativas particularmente úteis na prevenção de doenças relacionadas com estresse oxidativo.

Palavras-chave: Plantago coronopus, halófitas, fitoconstituintes, fenólicos, atividade antioxidante. 


\section{Introduction}

Plantago coronopus, commonly known as buckshorn plantain ("diabelha" in Portugal), is a medicinal halophyte belonging to the genus Plantago L., the largest of the Plantaginaceae family (Castroviejo et al., 2009; Ksouri et al., 2012). This salt-tolerant worldwide-distributed herbaceous plant, usually annual or biennial, grows on saline or disturbed areas, mainly in coastal habitats where it is exposed to fluctuating environmental conditions (Castroviejo et al., 2009). P. coronopus is edible and cooked as a vegetable in Balkan traditional cuisine, its leaves are salad ingredients in France and Italy, and it is a potentially important cash crop for animal feeding (Gálvez et al., 2005; Redzic, 2006).

In folk medicine Plantago species are widely used, for example, for their anticancer, antimicrobial, anti-viral, anti-inflammatory, analgesic, astringent, expectorant and diuretic properties (Gonçalves and Romano, 2016; Ksouri et al., 2012). P. coronopus in particular has several described ethnomedicinal uses in several countries, such as analgesic, anti-inflammatory, antipyretic, anticancer, emollient and to treat the respiratory system (Ksouri et al., 2012; Redzic, 2006). Several Plantago species display an array of bioactivities such as antioxidant, cytotoxic, anti-inflammatory and antiviral that can account for their medicinal uses (Beara et al., 2009, 2012a, b; Gálvez et al., 2003, 2005; Gonçalves and Romano, 2016; Ksouri et al., 2012). In fact, this genus contains a high amount of primary and secondary metabolites like phenolic acids, flavonoids, coumarins, lignans, glycosides, triterpenes and polysaccharides that can be responsible for those bioactivities (Beara et al., 2009, 2012a, b; Gonçalves and Romano, 2016; Jurišić Grubešić et al., 2013; Janković et al., 2012; Ksouri et al., 2012). Moreover, it is known that other Plantago species, namely P. major, $P$. lanceolata and P. media are valuable sources of amino acids and minerals, which may contribute for their use as an ingredient in human nutrition (Guil-Guerrero, 2001; Amaglo et al., 2010).

Reports on biological activities of $P$. coronopus are scarce and include cytotoxic, anti-inflammatory and anti-radical properties mainly of leaf extracts (Gálvez et al., 2003, 2005; Rodrigues et al., 2014). Some phenolic compounds and glycosides are described in leaves or aerial parts of this species (Gálvez et al., 2003, 2005; Jurišić Grubešić et al., 2013; Janković et al., 2012). Also, comparative studies of the biological activities of different anatomical organs of this species were not found. Therefore, considering the high potential of Plantago species as a source of biologically active compounds and the lack of information regarding P. coronopus, this work aimed to evaluate the antioxidant potential and phenolic composition of organic and water extracts from roots, leaves and flowers of P. coronopus, along with the amino acid and mineral content of leaves. This report could provide useful knowledge for the development of high added value health promoting commodities from $P$. coronopus.

\section{Materials and Methods}

\subsection{Chemicals}

All chemicals used were of analytical grade. Reagents 1,1-diphenyl-2picrylhydrazyl (DPPH), 2,2'-azino-bis(3-ethylbenzothiazoline-6-sulfonic acid) (ABTS), sulphanilamide, $\mathrm{N}$-(1-naphthyl) ethylenediamine dihydrochloride (NED), ethylenediamine tetraacetic acid (EDTA), pyrocatechol violet, sodium nitrite, aluminium chloride, butylated hydroxytoluene (BHT), and all commercial standards were purchased from Sigma-Aldrich (Germany). Merck (Germany) supplied phosphoric acid and Folin-Ciocalteau phenol reagent. Additional reagents and solvents were obtained from VWR International (Belgium).

\subsection{Plant collection}

Whole plants of Plantago coronopus were collected in Ludo, Ria Formosa, a coastal lagoon in south Portugal, in June 2013 ( $37^{\circ} 01$ ' 14.2” N $\left.7^{\circ} 53^{\prime} 05.5^{\prime \prime \prime} \mathrm{W}\right)$, and its taxonomical classification was performed by the botanist Dr. Manuel J. Pinto (National Museum of Natural History, University of Lisbon, Botanical Garden, Portugal). A voucher specimen is kept in the herbarium of the Marbiotech Laboratory (voucher MBH02). Plants were divided in roots, leaves and flowers, oven dried for 3 days at $50{ }^{\circ} \mathrm{C}$, milled and stored at $-20^{\circ} \mathrm{C}$ until use.

\subsection{Extracts preparation}

Dried biomass was first mixed with hexane $(1: 10, \mathrm{w} / \mathrm{v})$, using a disperser (2 min, IKA T10B Ultra-Turrax) for cell disruption, vortexed for $1 \mathrm{~min}$ at room temperature (RT) and centrifuged $(6000 \mathrm{~g}, 10 \mathrm{~min})$. Extraction was repeated three times, and the supernatants combined and filtered (Whatman no. 4). Pellets were then extracted sequentially with solvents of increasing polarity, namely ethyl acetate, methanol and water. All the extracts were vacuum-dried and re-suspended in the corresponding solvent and/or dimethyl sulfoxide (DMSO) to a final concentration of $10 \mathrm{mg} / \mathrm{mL}$ and stored at $-20{ }^{\circ} \mathrm{C}$.

\subsection{Phytochemical composition of the extracts}

\subsubsection{Total polyphenols (TPC), flavonoids (TFC) and} condensed tannin (CTC) content

TPC was determined by the Folin-Ciocalteau assay according to Velioglu et al. (1998), adapted to 96-well plates (described in Rodrigues et al., 2015). Absorbance was measured at $725 \mathrm{~nm}$ using gallic acid as standard and results were expressed as milligrams of gallic acid equivalents per grams of biomass dried weight (mg GAE/g dw). TFC was estimated by the aluminium chloride colorimetric method, adapted to 96-well plates (Zou et al., 2011). Absorbance was measured at $510 \mathrm{~nm}$ using rutin as standard and results were expressed as rutin equivalents ( $\mathrm{mg} \mathrm{RE} / \mathrm{g} \mathrm{dw}$ ). The CTC was assessed by the 4-dimethylaminocinnamaldehyde (DMACA) method, adapted to 96-well plates (Zou et al., 2011). Absorbance was measured at $640 \mathrm{~nm}$ using catechin as standard and results were expressed as $\mathrm{mg}$ of catechin equivalents (mg CE/g dw). 


\subsubsection{Phenolic composition by HPLC}

The extracts were dissolved in ultrapure water, or other appropriate solvent, at the concentration of $10 \mathrm{mg} / \mathrm{mL}$ and analysed by HPLC-DAD (Agilent 1100 Series LC system, Germany) equipped with vacuum degasser (G1322A), quaternary pump (G1311A), autosampler (G1313A), thermostated column compartment (G1316A) and a diode array detector (G1315B). Data acquisition and instrumental control were performed with LC3D ChemStation software (Rev.A.10.02[1757] version, Agilent Technologies). Analyses were carried out on a mediterranea sea 18 column $(15 \times 0.21 \mathrm{~cm}, 5 \mu \mathrm{m}$ particle size; Teknokroma, Spain). The mobile phase consisted on a mixture of methanol (solvent $\mathrm{A}$ ) and $2.5 \%$ acetic acid aqueous solution, following a gradient of $0-5 \mathrm{~min}: 10 \% \mathrm{~A}$, 5-10 min: $10-30 \%$ A, 10-40 min: 30-90\% A, 40-45 min: 90\% A, 45-55 min: 90-10\% A, and 55-60 min: 10\% A, with a flow of $0.5 \mathrm{ml} / \mathrm{min}$. The injection volume was $20 \mu \mathrm{l}$ with a draw speed of $200 \mu \mathrm{l} / \mathrm{min}$; the detector was set at 210 , 280 (for quantification), 320 and $350 \mathrm{~nm}$. Levels of the different compounds were extrapolated from calibration curves prepared individually for each commercial standard in methanol (apigenin, butylated hydroxytoluene (BHT), caffeic acid, catechin, chlorogenic acid, coumaric acid, epicatechin, epigallocatechin, epigallocatechin gallate, ferulic acid, flavone, gallic acid, gentisic acid, 4-hydroxybenzaldehyde, m-hydroxybenzoic acid, p-hydroxybenzoic acid, luteolin, oleanolic acid, quercetin, resveratrol, rosmarinic acid, rutin hydrate, salicylic acid, syringic acid, transcinnamic acid, uvaol, vanillic acid and verbascoside) or ultrapure water (luteolin-7-O-glucoside), at $1.00 \mathrm{mg} / \mathrm{L}$, and diluted to desired concentrations with ultrapure water.

\subsection{Antioxidant activity}

\subsubsection{Radical scavenging activities (RSA) on DPPH,} nitric oxide (NO) and ABTS radicals

The capacity to scavenge the free radicals DPPH, NO and ABTS was evaluated according to Brand-Williams et al. (1995), Baliga et al. (2003) and Re et al. (1999), respectively, adapted to 96-well plates as described by Rodrigues et al. (2015). BHT (1 mg/mL) was used as positive control. Results were calculated as percentage of inhibition, relative to a control containing the extracts' solvent, and expressed as $\mathrm{IC}_{50}$ values (half maximal inhibitory concentration, ascertained for extracts with activities higher than $50 \%$ at $10 \mathrm{mg} / \mathrm{mL}$ ).

\subsubsection{Metal chelating activities on copper (CCA) and} iron (ICA)

The CCA and ICA were determined following Megías et al. (2009), as described by Rodrigues et al. (2015). Change in colour was measured at $632 \mathrm{~nm}$ for CCA and at 562 for ICA, using the synthetic metal chelator EDTA as positive control $(1 \mathrm{mg} / \mathrm{mL})$. Results were expressed as $\mathrm{IC}_{50}$ values $(\mathrm{mg} / \mathrm{mL})$.

\subsection{Total amino acids}

For the analysis of total amino acids samples from leaves were hydrolysed with hydrochloric acid (6M) at $106^{\circ \circ} \mathrm{C}$ for $24 \mathrm{~h}$ in nitrogen-flushed glass vials and afterwards processed and analysed using the PicoTag method (Waters, USA; Cohen et al., 1988). Amino acid analyses were performed by HPLC in a Waters Reversed-Phase Amino Acid Analysis System equipped with a PicoTag column $(3.9 \times 300 \mathrm{~mm})$, using norleucine as an internal standard. Resulting peaks were analysed with the Breeze software (Waters, USA).

\subsection{Minerals}

Leaves were analysed for minerals (calcium - Ca, cadmium $-\mathrm{Cd}$, chromium $-\mathrm{Cr}$, copper $-\mathrm{Cu}$, iron $-\mathrm{Fe}$, magnesium $-\mathrm{Mg}$, manganese $-\mathrm{Mn}$, nickel $-\mathrm{Ni}$, lead $-\mathrm{Pb}$ and zinc $-\mathrm{Zn}$ ) by flame atomic absorption spectrometry or flame atomic emission spectrometry (potassium $-\mathrm{K}$ and sodium - Na) (novAA® 350 - Analytik Jena, SW-version Aspect LS 1.3.2.0), after acid digestion with nitric acid, filtration and dilution. Working standards of different concentrations were prepared from certified standard solutions; for analytical quality assurance, results were corrected by subtracting a blank from the analysed metal concentrations and samples were analysed in triplicate. Detection limits were: Ca $1.234 \mathrm{mg} / \mathrm{L}, \mathrm{Cd} 0.121 \mathrm{mg} / \mathrm{L}$, $\mathrm{Cr} 0.596 \mathrm{mg} / \mathrm{L}, \mathrm{Cu} 0.356 \mathrm{mg} / \mathrm{L}, \mathrm{Fe} 0.167 \mathrm{mg} / \mathrm{L}$, $\mathrm{Mg} 0.031 \mathrm{mg} / \mathrm{L}, \mathrm{Mn} 0.044 \mathrm{mg} / \mathrm{L}$, Ni $0.015 \mathrm{mg} / \mathrm{L}$, $\mathrm{Pb} 1.226 \mathrm{mg} / \mathrm{L}, \mathrm{Zn} 0.081 \mathrm{mg} / \mathrm{L} ; \mathrm{K}$ and Na detection limits were not determined. Results were expressed as $\mathrm{mg} / \mathrm{g} \mathrm{dw}$.

\subsection{Statistical analysis}

Results were expressed as mean \pm standard deviation (sd), and experiments were conducted at least in triplicate. Significant differences $(p<0.05)$ were assessed by one-way analysis of variance (ANOVA) or Kruskal Wallis one-way analysis of variance on ranks when parametricity of data did not prevail. If significant, the pairwise multiple comparison tests Tukey or Dunn's were applied. Statistical analyses were performed using XLStat2014 ${ }^{\circledR}$. IC $_{50}$ values were computed by curve fitting in GraphPad Prism ${ }^{\circledR}$ version 6.0c.

\section{Results and Discussion}

\subsection{Phytoconstituents of P. coronopus: phenolic composition}

Phenolic compounds are ubiquitous in plants but as each plant contains different polyphenolic mixtures, characterization of phenolic groups is often difficult. Hence, fast-screening colorimetric (spectrophotometric) techniques are frequently used for the assessment of the total phenolic content or content of specific phenolic classes (Naczk and Shahidi, 2004). P. coronopus extracts had high amounts of total polyphenols, flavonoids and condensed tannins (Table 1). Natural extracts are classified as rich in phenolic compounds when their TPC (expressed as GAE values) is higher than $20 \mathrm{mg} / \mathrm{g}$ (Ksouri et al., 2012; Rodrigues et al., 2015) and in this sense all P. coronopus 
Table 1. Phenolic content ${ }^{1}$ (mg/g biomass dw) in P. coronopus roots, leaves and flowers extracts: total polyphenols (TPC), total flavonoids (TFC) and condensed tannin (CTC) content. In each column different letters mean significant statistical differences between phenolic contents of the extracts $(p<0.05)$.

\begin{tabular}{clccc}
\hline \multirow{2}{*}{ Organ } & \multicolumn{1}{c}{ Extract } & $\begin{array}{c}\text { TPC } \\
(\mathbf{m g ~ G A E} / \mathbf{g})\end{array}$ & $\begin{array}{c}\text { TFC } \\
(\mathbf{m g ~ R E} / \mathbf{g})\end{array}$ & $\begin{array}{c}\text { CTC } \\
(\mathbf{m g ~ C E} / \mathbf{g})\end{array}$ \\
\hline \multirow{2}{*}{ Roots } & Hexane & $0.56 \pm 0.02^{\mathrm{g}}$ & $0.10 \pm 0.05^{\mathrm{b}}$ & $0.04 \pm 0.00^{\mathrm{d}}$ \\
& Ethyl acetate & $1.34 \pm 0.05^{\mathrm{fg}}$ & $5.38 \pm 0.85^{\mathrm{b}}$ & $0.19 \pm 0.03^{\mathrm{d}}$ \\
& Methanol & $30.6 \pm 1.70^{\mathrm{a}}$ & $82.2 \pm 19.4^{\mathrm{ab}}$ & $1.21 \pm 0.18^{\mathrm{cd}}$ \\
& Water & $8.78 \pm 0.51^{\mathrm{e}}$ & $16.5 \pm 2.77^{\mathrm{b}}$ & $1.32 \pm 0.07^{\mathrm{cd}}$ \\
& Total & $\mathbf{4 1 . 3}$ & $\mathbf{1 0 4}$ & $\mathbf{2 . 7 6}$ \\
& Hexane & $2.07 \pm 0.08^{\mathrm{fg}}$ & $12.1 \pm 3.20^{\mathrm{b}}$ & $1.11 \pm 0.14^{\mathrm{cd}}$ \\
& Ethyl acetate & $2.43 \pm 0.12^{\mathrm{f}}$ & $12.6 \pm 2.48^{\mathrm{b}}$ & $0.74 \pm 0.08^{\mathrm{cd}}$ \\
& Methanol & $28.1 \pm 1.07^{\mathrm{b}}$ & $146 \pm 18.3^{\mathrm{a}}$ & $6.17 \pm 1.06^{\mathrm{a}}$ \\
& Water & $9.98 \pm 1.57^{\mathrm{de}}$ & $56.0 \pm 15.2^{\mathrm{ab}}$ & $3.14 \pm 0.35^{\mathrm{b}}$ \\
& Total & $\mathbf{4 2 . 6}$ & $\mathbf{2 2 6}$ & $\mathbf{1 1 . 2}$ \\
& Hexane & $1.26 \pm 0.07^{\mathrm{fg}}$ & $7.73 \pm 1.27^{\mathrm{b}}$ & $0.48 \pm 0.05^{\mathrm{d}}$ \\
& Ethyl acetate & $1.53 \pm 0.14^{\mathrm{fg}}$ & $1.60 \pm 0.56^{\mathrm{b}}$ & $0.36 \pm 0.06^{\mathrm{d}}$ \\
& Methanol & $15.7 \pm 1.41^{\mathrm{c}}$ & $34.0 \pm 9.41^{\mathrm{b}}$ & $3.19 \pm 0.26^{\mathrm{b}}$ \\
& Water & $11.0 \pm 1.33^{\mathrm{d}}$ & $13.4 \pm 2.63^{\mathrm{b}}$ & $1.96 \pm 0.20^{\mathrm{c}}$ \\
& Total & $\mathbf{2 9 . 5}$ & $\mathbf{5 6 . 8}$ & $\mathbf{6 . 0 0}$ \\
\hline
\end{tabular}

${ }^{1}$ Data represent the mean $\pm \mathrm{sd}(n \geq 6)$. GAE - Gallic acid equivalents; RE - Rutin equivalents; $\mathrm{CE}$ - Catechin equivalents.

organs had high phenolic content. TPC was within the range of values found in literature for $P$. coronopus and for other Plantago species (Beara et al., 2009; Janković et al., 2012; Rodrigues et al., 2014). Globally, leaves had the highest content of all phenolic groups, an accumulation pattern possibly linked to the phenolics role in plant physiological survival since phenolics, and flavonoids in particular, can act like UV filters protecting the photosynthetic tissues in the leafs, the largest radiation-exposed area (Harborne and Williams, 2000). In fact, flavonoids were the major constituents of almost all extracts, ranging from $0.10 \mathrm{mg} \mathrm{RE} / \mathrm{g}$ in the hexane extract of roots to $146 \mathrm{mg} \mathrm{RE} / \mathrm{g}$ in the methanol extract of leaves. The total flavonoid contents of P. coronopus' organs were particularly higher than those found in the literature for different plantains, for example P. major and P. lanceloata (Beara et al., 2009, 2012b). The observed differences may be related to different extraction procedures and/or analytical methods used, or harvesting time and environmental characteristics that can also influence compounds concentration in plantains (Tamura and Nishibe, 2002). Nonetheless, flavonoids are one of the most characteristic classes of compounds in Plantago species (Ksouri et al., 2012). Although polyphenolic content varied considerably amongst the different extracts, the more polar extracts, particularly methanol, had the highest phenolic contents. Solvents' polarity defines the composition of the obtained extracts and methanol is known for its affinity to a broad diversity of bioactive compounds, namely phenolics (Khoddami et al., 2013).

The HLPC-DAD analysis of $P$. coronopus extracts led to the identification of eighteen compounds: ten phenolic acids, seven flavonoids and one other polyphenol (Table 2). From these, only a few were already described in $P$. coronopus, namely caffeic acid, verbascoside, quercetin,
luteolin-7-O-glucoside, luteolin and apigenin (Jurišić Grubešić et al., 2013; Janković et al., 2012). Salicylic acid and epicatechin were, to the best of our knowledge, here firstly described in Plantago species.

The phenolic profile of $P$. coronopus varied according to the organ and extraction solvent. Flowers had a higher phenolic diversity with 17 out of the 18 compounds identified and two of them exclusively present in this organ: caffeic acid and catechin. Verbascoside was the main phenolic identified in all organs corresponding to $95 \%, 78 \%$ and $85 \%$ of the total phenolics in roots, leaves and flowers, respectively. Roots had the highest content of verbascoside, followed by leaves and flowers, which might be explained by the allelopathic properties of that compound on soil phytopathogenic fungi, inhibiting their growth (Egorov et al., 2004). Described as a main compound in plantains, verbascoside levels in this study were higher than those reported by other authors for the aerial parts of $P$. coronopus and five other Plantago species (Janković et al., 2012). This major component has known antioxidant, anti-inflammatory, and antifungal properties, along with cytotoxic activity (Egorov et al., 2004; Gálvez et al., 2005; Ksouri et al., 2012).

Luteolin-7-O-glucoside was the second most abundant phenolic identified, with similar concentrations between organs, and its levels were higher than those reported for P. coronopus by other authors (Janković et al., 2012). This compound has demonstrated antioxidant and cytotoxic activities (Gálvez et al., 2003, 2005). Ferulic, salicylic and rosmarinic acids followed as major compounds identified, all present in higher amounts in roots. Ferulic acid plays a vital role in providing rigidity to plant cell walls (Kumar and Pruthi, 2014) and has many recognized bioactivities particularly antioxidant, anti-inflammatory, neuroprotective 


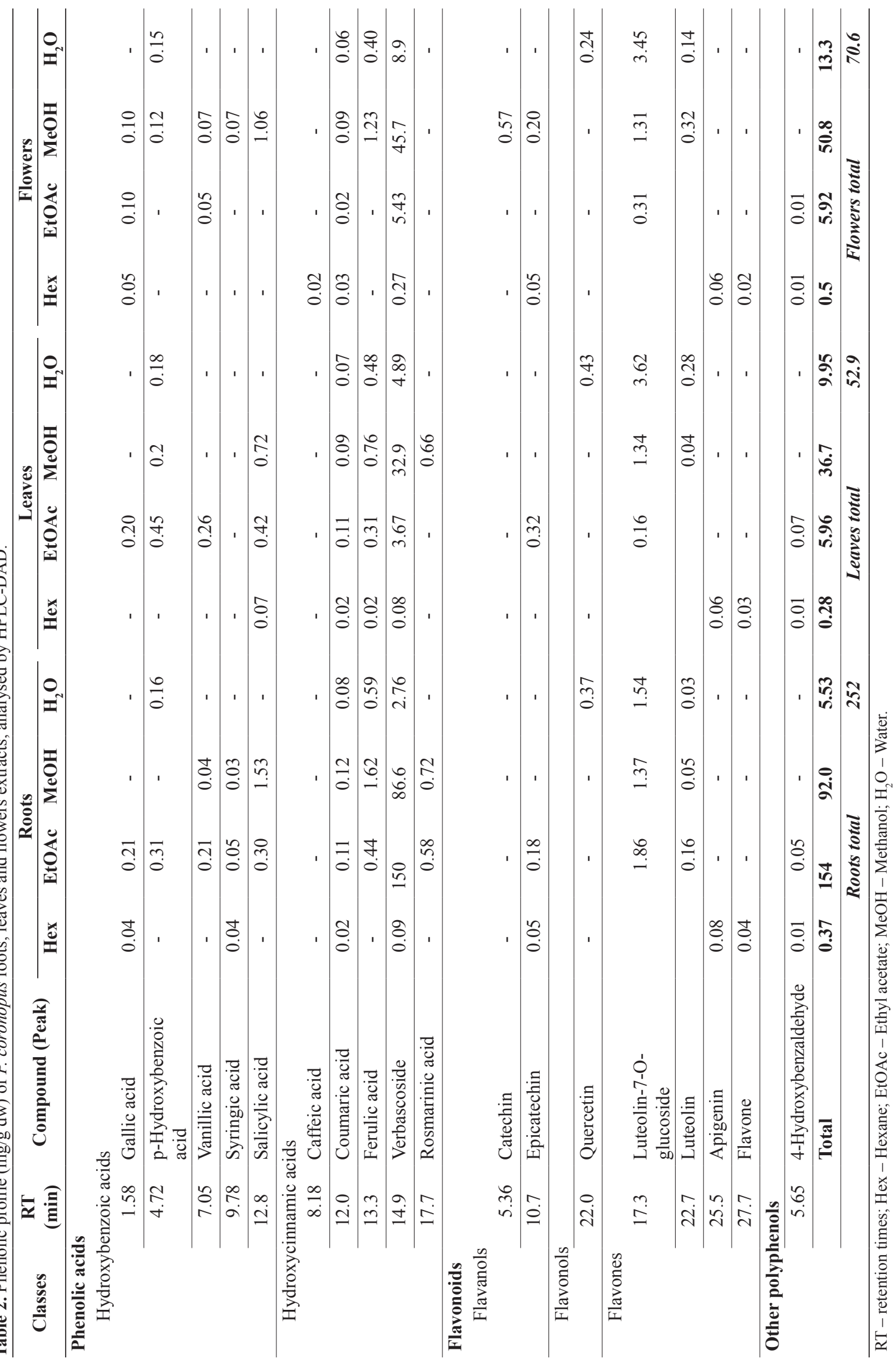


and anti-carcinogenic (Chao and Lin, 2011). Salicylic acid was here identified for the first time in Plantago species. This phenolic was first isolated from willow bark (Salix spp.) in pursuit of the active ingredient responsible for the tree's medicinal properties and soon after acetylsalicylic acid (aspirin) was synthesized (Raskin, 1992). Salicylic acid has been implicated in the improvement of stress tolerance in plants, like acclimation to saline stress (Singh and Gautam, 2013), and has anti-inflammatory, antipyretic, analgesic, antiseptic, antifungal and keratolytic properties (Khadem and Marles, 2010). Rosmarinic acid (RA), although already isolated in P. lagopus (Fiz et al., 2000), is here firstly quantified in the genus. The RA content was within the range of that determined for Rosmarinus officinalis, a traditional folk remedy from which the compound was firstly isolated (Moreno et al., 2006; Petersen and Simmonds, 2003). This phenolic has been reported as a phago-deterrent used by plants as a defence against pathogens and herbivores (Petersen and Simmonds, 2003), and has antioxidant, antimicrobial, neuroprotective, anti-inflammatory and antiviral activities (Moreno et al., 2006; Petersen and Simmonds, 2003). These major phenolic compounds identified in P. coronopus extracts (verbascoside, luteolin-7-O-glucoside, ferulic, salicylic and RA) can support the main traditional medicinal uses given to this halophyte given their reported bioactivities.

The $p$-hydroxybenzoic and vanillic acids, quercetin and epicatechin were also detected in high levels in all organs (especially in leaves), along with luteolin (higher in flowers), gallic and coumaric acids (higher in roots), coumaric being the only phenolic present in all extracts. The values obtained for the phenolic acids were similar to those found in literature for several other plantain species
(Beara et al., 2012a, b; Janković et al., 2012). Those compounds are allelopathic (Seal et al., 2004) (except gallic acid) and have several bioactivities, for example antimutagenic and antitumor ( $p$-hydroxybenzoic, gallic and coumaric acids), antimicrobial ( $p$-hydroxybenzoic, vanillic and coumaric acids), anti-inflammatory (gallic and coumaric acids) and neuroprotective (coumaric acid) (Khadem and Marles, 2010; Ksouri et al., 2012; Vauzour et al., 2010). As for flavonoids, quercetin and luteolin were abundant in P. coronopus (Table 2). These flavonoids are reported to exert a variety of effects, for example neuroprotective and antimicrobial (quercetin, epicatechin), antiproliferative and anti-adipogenic (quercetin) and cytotoxic (luteolin) (Huang et al., 2006; Ksouri et al., 2012; Vauzour et al., 2010; Vuuren, 2008). The minor compounds identified in $P$. coronopus extracts were 4-hydroxybenzaldehyde, apigenin and flavone, present only on the less polar extracts of all organs, along with syringic acid, found in roots and flowers.

\subsection{Antioxidant activity}

The crude extracts of roots, leaves and flowers were tested for radical scavenging and metal chelating potential using complementary in vitro assays, attending at the multifaceted aspects of antioxidants and their reactivity. It is increasingly documented that compounds with RSA effectively prevent oxidative damage and their consumption has become a strategy to address health challenges (Ksouri et al., 2012). Moreover, agents with the ability to chelate metal ions like $\mathrm{Fe}$ and $\mathrm{Cu}$, through the formation of inactive complexes, can prevent metal-induced ROS and oxidative stress (Rodrigues et al., 2014, 2015).

The RSA and metal chelating properties were highly variable among $P$. coronopus organs, as shown in Table 3 .

Table 3. Antioxidant activity of $P$. coronopus roots, leaves and flowers extracts $\left(\mathrm{IC}_{50}\right.$ values, $\left.\mathrm{mg} / \mathrm{ml}\right)$ : radical scavenging on DPPH, ABTS and NO radicals, and metal chelating activities on copper (CCA) and iron (ICA).

\begin{tabular}{|c|c|c|c|c|c|c|}
\hline Organ & Extract & DPPH & ABTS & NO & CCA & ICA \\
\hline \multirow{4}{*}{ Roots } & Hexane & $>10$ & $2.43 \pm 0.27^{\mathrm{a}}$ & $3.66 \pm 0.37^{\mathrm{cd}}$ & $4.76 \pm 0.19^{\mathrm{cd}}$ & $1.95 \pm 0.13^{\mathrm{c}}$ \\
\hline & $\begin{array}{l}\text { Ethyl } \\
\text { acetate }\end{array}$ & $0.47 \pm 0.03^{\mathrm{g}}$ & $0.57 \pm 0.03^{\mathrm{f}}$ & $6.71 \pm 0.49^{b}$ & $4.28 \pm 0.31^{\mathrm{ef}}$ & $>10$ \\
\hline & Methanol & $0.51 \pm 0.04^{\mathrm{g}}$ & $0.56 \pm 0.02^{f}$ & $>10$ & $5.74 \pm 0.40^{\mathrm{b}}$ & $>10$ \\
\hline & Water & $0.81 \pm 0.09^{\mathrm{ef}}$ & $1.79 \pm 0.11^{\mathrm{b}}$ & $>10$ & $4.07 \pm 0.48^{f}$ & $6.29 \pm 0.60^{\mathrm{a}}$ \\
\hline \multirow{4}{*}{ Leaves } & Hexane & $8.56 \pm 1.03^{\mathrm{a}}$ & $>10$ & $3.21 \pm 0.31^{\mathrm{d}}$ & $7.20 \pm 0.77^{\mathrm{a}}$ & $1.08 \pm 0.07^{\mathrm{e}}$ \\
\hline & $\begin{array}{l}\text { Ethyl } \\
\text { acetate }\end{array}$ & $1.66 \pm 0.23^{c}$ & $1.85 \pm 0.17^{b}$ & $10.5 \pm 1.18^{a}$ & $>10$ & $>10$ \\
\hline & Methanol & $1.21 \pm 0.06^{\mathrm{d}}$ & $1.39 \pm 0.15^{\mathrm{d}}$ & $>10$ & $7.75 \pm 0.90^{\mathrm{a}}$ & $>10$ \\
\hline & Water & $1.88 \pm 0.23^{\mathrm{c}}$ & $1.58 \pm 0.09^{c}$ & $3.83 \pm 0.31^{\mathrm{c}}$ & $4.61 \pm 0.19^{\text {de }}$ & $5.43 \pm 0.28^{b}$ \\
\hline \multirow{4}{*}{ Flowers } & Hexane & $>10$ & $>10$ & $>10$ & $4.80 \pm 0.26^{\mathrm{cd}}$ & $1.29 \pm 0.09^{\mathrm{d}}$ \\
\hline & $\begin{array}{l}\text { Ethyl } \\
\text { acetate }\end{array}$ & $4.33 \pm 0.17^{b}$ & $2.55 \pm 0.22^{\mathrm{a}}$ & $>10$ & $>10$ & $>10$ \\
\hline & Methanol & $0.88 \pm 0.05^{\mathrm{e}}$ & $0.82 \pm 0.05^{\mathrm{e}}$ & $>10$ & $5.50 \pm 0.72^{\mathrm{bc}}$ & $>10$ \\
\hline & Water & $0.76 \pm 0.05^{\mathrm{f}}$ & $1.33 \pm 0.02^{\mathrm{d}}$ & $3.55 \pm 0.55^{\mathrm{cd}}$ & $3.03 \pm 0.15^{\mathrm{g}}$ & $5.77 \pm 0.64^{\mathrm{ab}}$ \\
\hline \multicolumn{2}{|l|}{ BHT } & $0.32 \pm 0.02^{\mathrm{h}}$ & $0.11 \pm 0.01^{\mathrm{g}}$ & & & \\
\hline \multicolumn{2}{|c|}{ Ascorbic acid } & & & $2.34 \pm 0.26^{\mathrm{e}}$ & & \\
\hline \multicolumn{2}{|c|}{ EDTA } & & & & $0.13 \pm 0.01^{\mathrm{h}}$ & $0.07 \pm 0.00^{\mathrm{f}}$ \\
\hline
\end{tabular}

In each column different letters mean significant statistical differences between $\mathrm{IC}_{50}$ values of the extracts $(p<0.05)$. 
Roots had the highest RSA towards DPPH and ABTS radicals, namely in the ethyl acetate and methanol extracts, while the NO radical was best scavenged by the leaves' hexane extract, followed by roots' hexane and flowers' water extracts. The $\mathrm{Cu}^{2+}$ and $\mathrm{Fe}^{2+}$ chelating capacities of P. coronopus extracts were moderate; the water extract from flowers had the highest $\mathrm{Cu}^{2+}$ chelating potential, while the hexane extract from leaves displayed the best capacity to chelate $\mathrm{Fe}^{2+}$. Extracts from the leaves of P. coronopus had lower RSA activity than those reported for leaves' extracts of different Plantago species (Beara et al., 2009, 2012a,b; Gálvez et al., 2005). These differences can be due to the different extracts tested, since parameters like solvent type and extraction method may influence the extracted antioxidant compounds (Khoddami et al., 2013), or due to biological and/or environmental conditions that influence the plants composition and contents of active constituents (Ksouri et al., 2012; Tamura and Nishibe, 2002).

Overall, our results showed variability between P. coronopus organs regarding antioxidant activities: root extracts had better radical scavenging activity towards DPPH and ABTS radicals, leaves had high RSA particularly on NO radical and greater iron chelating ability, while flower extracts were best at chelating copper. This organ-related bioactivity has been described for other halophytes, such as M. edule and Limonium algarvense where it was attributed to different accumulation patterns of secondary metabolites, mainly phenolics that differ between organs (Ksouri et al., 2008; Rodrigues et al., 2015). However, the highest content of all phenolic groups where mainly found on leaves (Table 1). It is commonly found in literature that a high phenolic content correlates with antioxidant activity (Ksouri et al., 2012) but other authors found no such relation (Kähkönen et al., 1999). In fact, colorimetric assays give estimates of total phenolic content (Ignat et al., 2011) but may not necessarily incorporate all the antioxidants present in an extract (Tawaha et al., 2007). Phenolic compounds are known powerful antioxidants (Ksouri et al., 2012; Takao et al., 2015), and the higher radical scavenging or chelating activities of each organ may be explained by the amount and nature of individual phenolic compounds (Table 2). Roots had a great amount of verbascoside, a known antioxidant, particularly in the extracts with the highest RSA, along with higher levels of ferulic, salicylic, rosmarinic, gallic and coumaric acids; leaves had higher levels of luteolin-7-O-glucoside, $p$-hydroxybenzoic acid, vanillic acid, quercetin and epicatechin, and flowers had caffeic acid and catechin exclusively along with greater phenolic diversity, possibly conferring to each of these organs their specific properties.

\subsection{Phytoconstituents of P. coronopus: minerals and amino acids in leaves}

Several species belonging to the Plantago genus, such as $P$. major, $P$. lanceolata and $P$. media, contain interesting levels of essential amino acids and minerals, thus increasing their potential as food and/or as food ingredients (Guil-Guerrero, 2001; Amaglo et al., 2010).
In this sense, the edible organs of $P$. coronopus, i.e. the leaves, were analysed for minerals and amino acids, and results are summarized on Tables 4 and 5. P. coronopus has high levels of $\mathrm{Na}(50.0 \mathrm{mg} / \mathrm{g} \mathrm{dw})$, is a good source of $\mathrm{Ca}(14.0 \mathrm{mg} / \mathrm{g})$ surpassed only by Ca-rich leaves like arugula or watercress (19.3 and $24.5 \mathrm{mg} / \mathrm{g} \mathrm{dw}$; USDA $2015)$, and has also good levels of Fe $(0.41 \mathrm{mg} / \mathrm{g} \mathrm{dw})$ and $\mathrm{Mg}$ (6.34 mg/g), comparable to dark green vegetables like spinach (USDA 2015). The levels of $\mathrm{Ca}, \mathrm{Mg}$ and $\mathrm{K}$ are higher than those reported for other halophytes such as Salicornia species (Díaz et al., 2013; Essaidi et al., 2013), whereas $\mathrm{Mn}$ and $\mathrm{Zn}$ were found in small quantities just like in other vegetables (Díaz et al., 2013; Essaidi et al., 2013). When compared to other Plantago species (P. major, P. media, . lanceolata), $P$. coronopus has higher $\mathrm{Na}, \mathrm{Ca}$, $\mathrm{Mg}$, Fe and Zn levels (Guil-Guerrero, 2001). Moreover, potentially toxic minerals like $\mathrm{Cu}, \mathrm{Cr}, \mathrm{Ni}, \mathrm{Cd}$ and $\mathrm{Pb}$ were not detected in this study.

Regarding the amino acid (AA) profile of $P$. coronopus leaves (Table 5) arginine was the major essential AA $(10.2 \mathrm{mg} / \mathrm{g} \mathrm{dw})$ followed by leucine $(5.57 \mathrm{mg} / \mathrm{g} \mathrm{dw})$ and threonine $(5.22 \mathrm{mg} / \mathrm{g} \mathrm{dw})$, while tryptophan $(0.05 \mathrm{mg} / \mathrm{g} \mathrm{dw})$ and histidine $(1.40 \mathrm{mg} / \mathrm{g} \mathrm{dw})$ were the minor AA. Arginine is a conditionally essential AA: it is required in higher amounts than can be produced during growth development, and dietary deficiency can result in metabolic, neurological or reproductive dysfunction (Wu, 2009). Our results indicate that Plantago's leaves are a good arginine source for young/developing mammals, akin to other vegetables like lettuce or asparagus (USDA, 2015). As for the other AA, threonine $(45.1 \mathrm{mg} / \mathrm{g}$ protein $\mathrm{dw}$ ) along with the sum of phenylalanine and tyrosine $(80.9 \mathrm{mg} / \mathrm{g}$ protein $\mathrm{dw})$ exceed the FAO/WHO (WHO, 1973) reference values for AA composition, making this plantain's leaves a good source for these AA. Tryptophan is the most limiting amino acid since it is in greater deficit, but the remaining amino acid levels in P. coronopus represent between $60 \%$ and $70 \%$

Table 4. Mineral content ${ }^{1}(\mathrm{mg} / \mathrm{g} \mathrm{dw})$ of $P$. coronopus leaves.

\begin{tabular}{cccc}
\hline Classification & Mineral & Symbol & Content \\
\hline Essential elements & & \\
Sodium & Na & $50.0 \pm 2.45$ \\
Calcium & $\mathbf{C a}$ & $14.0 \pm 0.55$ \\
Potassium & $\mathbf{K}$ & $8.02 \pm 0.12$ \\
Magnesium & $\mathbf{M g}$ & $6.34 \pm 0.28$ \\
Iron & $\mathbf{F e}$ & $0.41 \pm 0.02$ \\
Manganese & $\mathbf{M n}$ & $0.01 \pm 0.00$ \\
Zinc & $\mathbf{Z n}$ & $0.05 \pm 0.00$ \\
Copper & $\mathbf{C u}$ & BDL \\
Chromium & $\mathbf{C r}$ & BDL \\
Nickel & $\mathbf{N i}$ & BDL \\
Lead & $\mathbf{P b}$ & BDL \\
Cadmium & $\mathbf{C d}$ & BDL \\
\hline
\end{tabular}

${ }^{1}$ Data represent the mean $\pm \mathrm{sd}(n=3)$; BDL - below detection limit. 
Table 5. Amino acid profile ${ }^{1}$ (total AA, $\mathrm{mg} / \mathrm{g}$ leaves $\mathrm{dw}$ ) of P. coronopus leaves (mg/g protein $\mathrm{dw})$.

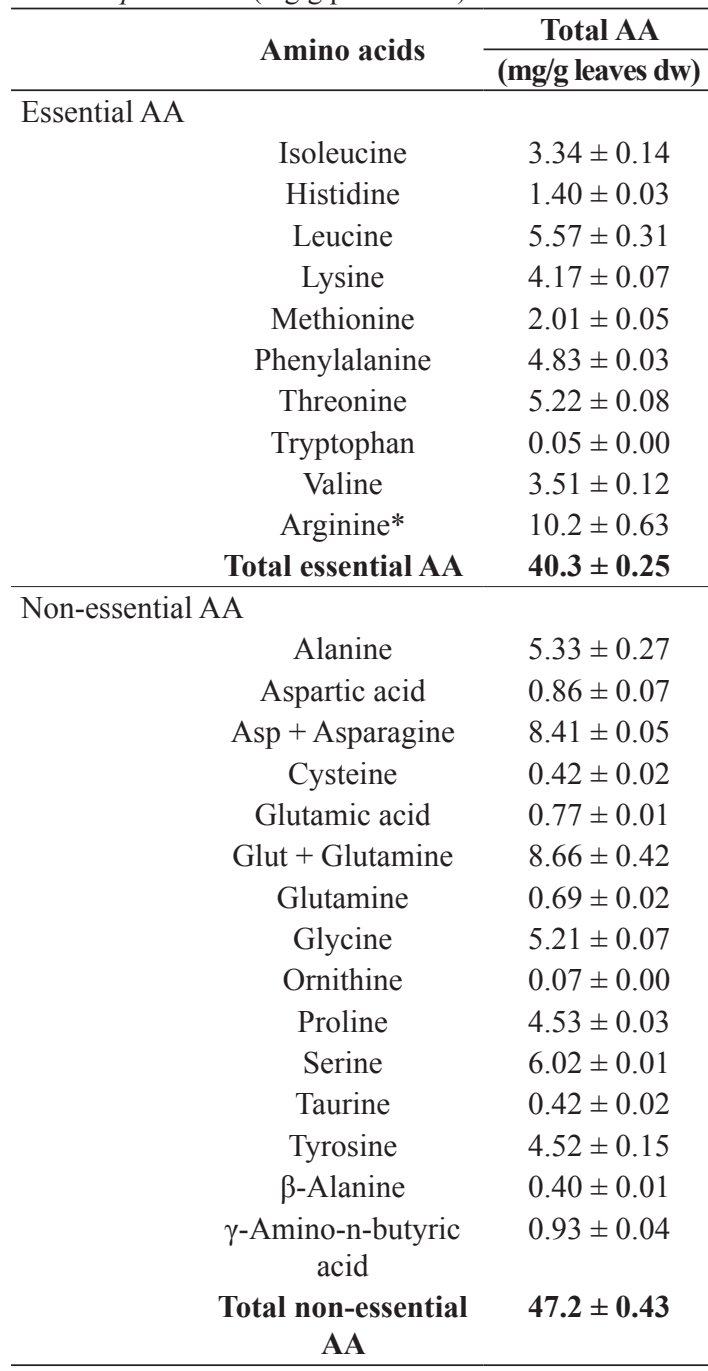

${ }^{1}$ Data represent the mean \pm sd $(n=2)$. *Conditionally essential: required in greater amounts than can be produced in growth development.

of the FAO/WHO (WHO, 1973) reference values. As for non-essential AA, although synthesized by the body, some can be conditionally essential in neonates (e.g. glutamine, taurine), under stress conditions (e.g. glutamine), or for carnivores and some fish (taurine) (Wu, 2009). In such cases $P$. coronopus leaves can be an additional source of these AA. To our knowledge, this is the first report of the presence of AA like ornithine, taurine, $\beta$-alanine and $\gamma$-amino-n-butyric acid in Plantago species and the first amino acid profile of $P$. coronopus.

\section{Conclusions}

Our results indicate that the edible halophyte $P$. coronopus has a high polyphenolic content and good antioxidant activity in its different anatomical organs. Moreover, its leaves are valuable source of minerals and amino acids. The phenolic richness known for a wide range of biological activities can explain the main traditional uses given to this plantain and, altogether, these results emphasize the potential of $P$. coronopus as a source of bioactive molecules, especially useful for the prevention of oxidative stress-related diseases, leading to the discovery of new food products.

\section{Acknowledgements}

This work was supported by XtremeBio project (PTDC/ MAR-EST/4346/2012), funded by FCT - Foundation for Science and Technology and Portuguese National Budget; it also received national funds through FCT project CCMAR/ Multi/04326/2013. Luísa Custódio was supported by FCT Investigator Programme (IF/00049/2012). Catarina Guerreiro Pereira acknowledges FCT for a $\mathrm{PhD}$ grant (SFRH/BD/94407/2013), Nuno R. Neng for the Post-Doc grant (SFRH/BPD/86071/2012), José M.F.Nogueira for the funding (UID/Multi/00612/2013).

\section{References}

AMAGLO, N.K., BENNETT, R.N., LO CURTO, R.B., ROSA, E.A.S., LO TURCO, V., GIUFFRIDA, A., CURTO, A.L., CREA, F. and TIMPO, G.M., 2010. Profiling selected phytochemicals and nutrients in different tissues of the multipurpose tree Moringa oleifera L. grown in Ghana. Food Chemistry, vol. 122, no. 4, pp. 1047-1054. http://dx.doi.org/10.1016/j.foodchem.2010.03.073.

BALIGA, M.S., JAGETIA, G.C., RAO, S.K. and BABU S, K., 2003. Evaluation of nitric oxide scavenging activity of certain spices in vitro: a preliminary study. Die Nahrung, vol. 47, no. 4, pp. 261-264. PMid:13678266. http://dx.doi.org/10.1002/ food.200390061

BEARA, I.N., LESJAK, M.M., ČETOJEVIĆ-SIMIN, D.D., ORČIĆ, D.Z., JANKOVIĆ, T., ANAČKOV, G.T. and MIMICA-DUKIĆ, N.M., 2012a. Phenolic profile, antioxidant, anti-inflammatory and cytotoxic activities of endemic Plantago reniformis G. Beck. Food Research International, vol. 49, no. 1, pp. 501-507. http:// dx.doi.org/10.1016/j.foodres.2012.08.006.

BEARA, I.N., LESJAK, M.M., JOVIN, E.Đ., BALOG, K.J., ANAČKOV, G.T., ORČIĆ, D.Z. and MIMICA-DUKIĆ, N.M., 2009. Plantain (Plantago L.) species as novel sources of flavonoid antioxidants. Journal of Agricultural and Food Chemistry, vol. 57, no. 19, pp. 9268-9273. PMid:19754195. http://dx.doi. org/10.1021/jf902205m

BEARA, I.N., LESJAK, M.M., ORČIĆ, D.Z., SIMIN, N.Đ., ČETOJEVIĆ-SIMIN, D.D., BOŽIN, B.N. and MIMICA-DUKIĆ, N.M., 2012b. Comparative analysis of phenolic profile, antioxidant, anti-inflammatory and cytotoxic activity of two closely-related Plantain species: Plantago altissima L. and Plantago lanceolata L. LWT - Food Science and Technology, vol. 47, no. 1, pp. 64-70. http://dx.doi.org/10.1016/j.lwt.2012.01.001.

BRAND-WILLIAMS, W., CUVELIER, M. and BERSET, C., 1995. Use of a free radical method to evaluate antioxidant activity. LWT - Food Science and Technology, vol. 28, no. 1, pp. 25-30. http://dx.doi.org/10.1016/S0023-6438(95)80008-5.

CASTROVIEJO, S., BENEDÍ, C., RICO, E., GÜEMES, J. and HERRERO, A., 2009. Flora iberica: plantas vasculares de la 
Peninsula Ibérica e Islas Baleares, Vol XIII Plantaginaceae Scrophulariaceae. Madrid: Real Jardín Botánico, CSIC. 539 p.

CHAO, W.-W. and LIN, B.-F., 2011. Bioactivities of major constituents isolated from Angelica sinensis (Danggui). Chinese Medicine, vol. 6, no. 29, pp. 1-7. PMid:21851645.

COHEN, S.A., MEYS, M. and TARVIN, T.L.,1988. The picotag method: a manual of advanced techniques for amino acids analysis. Millipore: Waters Chromatography Division Corp. 123 p.

DÍAZ, F.J., BENES, S.E. and GRATTAN, S.R., 2013. Field performance of halophytic species under irrigation with saline drainage water in the San Joaquin Valley of California. Agricultural Water Management, vol. 118, pp. 59-69. http://dx.doi.org/10.1016/j. agwat.2012.11.017.

EGOROV, T.A., GALKINA, T.G., BALASHOVA, T.A., ARSEN'EV, A.S., NIKONOROVA, A.K., BABAKOV, A.V. and GRISHIN, E.V., 2004. Phenolic glycoside isolated from seeds of the greater plantain (Plantago major L.). Doklady. Biochemistry and Biophysics, vol. 396, no. 1-6, pp. 132-135. PMid:15378908. http://dx.doi.org/10.1023/B:DOBI.0000033510.77794.a8.

ESSAIDI, I., BRAHMI, Z., SNOUSSI, A., KOUBAIER, H.B.H., CASABIANCA, H., ABE, N., OMRI, A.E., CHAABOUNI, M.M. and BOUZOUITA, N., 2013. Phytochemical investigation of Tunisian Salicornia herbacea L., antioxidant, antimicrobial and cytochrome P450 (CYPs) inhibitory activities of its methanol extract. Food Control, vol. 32, no. 1, pp. 125-133. http://dx.doi. org/10.1016/j.foodcont.2012.11.006.

FIZ, M.P.V., LANZA, A.M.D. and MATELLANO, L.F., 2000. Polyphenolic compounds from Plantago lagopus L. Zeitschrift für Naturforschung C. Journal of Biosciences, vol. 55, no. 1112, pp. 877-880. http://dx.doi.org/10.1515/znc-2000-11-1205. PMid:11204189.

GÁLVEZ, M., MARTÍN-CORDERO, C., HOUGHTON, P.J. and AYUSO, M.J., 2005. Antioxidant activity of methanol extracts obtained from Plantago species. Journal of Agricultural and Food Chemistry, vol. 53, no. 6, pp. 1927-1933. PMid:15769115. http://dx.doi.org/10.1021/jf048076s.

GÁLVEZ, M., MARTÍN-CORDERO, C., LÓPEZ-LÁZARO, M., CORTÉS, F. and AYUSO, M.J., 2003. Cytotoxic effect of Plantago spp. on cancer cell lines. Journal of Ethnopharmacology, vol. 88, no. 2-3, pp. 125-130. PMid:12963131. http://dx.doi.org/10.1016/ S0378-8741(03)00192-2.

GONÇALVES, S. and ROMANO, A., 2016. The medicinal potential of plants from the genus Plantago (Plantaginaceae). Industrial Crops and Products, vol. 83, pp. 213-226. http://dx.doi. org/10.1016/j.indcrop.2015.12.038.

GUIL-GUERRERO, J.L., 2001. Nutritional composition of Plantago species (P. major L., P. lanceolata L., and P. media L.). Ecology of Food and Nutrition, vol. 40, no. 5, pp. 481-495. http://dx.doi.org/10.1080/03670244.2001.9991663.

HARBORNE, J.B. and WILLIAMS, C.A., 2000. Advances in flavonoid research since 1992. Phytochemistry, vol. 55, no. 6, pp. 481-504. PMid:11130659. http://dx.doi.org/10.1016/S00319422(00)00235-1.

HUANG, S.-L., HSU, C.-L. and YEN, G.-C., 2006. Growth inhibitory effect of quercetin on SW 872 human liposarcoma cells. Life Sciences, vol. 79, no. 2, pp. 203-209. PMid:16455111. http://dx.doi.org/10.1016/j.1fs.2005.12.046.

IGNAT, I., VOLF, I. and POPA, V., 2011. A critical review of methods for characterisation of polyphenolic compounds in fruits and vegetables. Food Chemistry, vol. 126, no. 4, pp. 1821-1835. PMid:25213963. http://dx.doi.org/10.1016/j.foodchem.2010.12.026.

JANKOVIĆ, T., ZDUNIĆ, G., BEARA, I., BALOG, K., PLJEVLJAKUŠIĆ, D., STEŠEVIĆ, D. and ŠAVIKIN, K., 2012. Comparative study of some polyphenols in Plantago species. Biochemical Systematics and Ecology, vol. 42, pp. 69-74. http:// dx.doi.org/10.1016/j.bse.2012.02.013.

JURIŠIĆ GRUBEŠIĆ, R., SREČNIK, G., KREMER, D., VUKOVIĆ RODRÍGUEZ, J., NIKOLIĆ, T. and VLADIMIRKNEŽEVIĆ, S., 2013. Simultaneous RP-HPLC-DAD separation, and determination of flavonoids and phenolic acids in Plantago L. species. Chemistry \& Biodiversity, vol. 10, no. 7, pp. 1305-1316. PMid:23847075. http://dx.doi.org/10.1002/cbdv.201200210.

KÄHKÖNEN, M.P., HOPIA, A.I., VUORELA, H.J., RAUHA, J.-P., PIHLAJA, K., KUJALA, T.S. and HEINONEN, M., 1999. Antioxidant activity of plant extracts containing phenolic compounds. Journal of Agricultural and Food Chemistry, vol. 47, no. 10, pp. 3954-3962. PMid:10552749. http://dx.doi.org/10.1021/jf9901461.

KHADEM, S. and MARLES, R.J., 2010. Monocyclic phenolic acids; hydroxy- and polyhydroxybenzoic acids: occurrence and recent bioactivity studies. Molecules, vol. 15, no. 11, pp. 7985-8005. PMid:21060304. http://dx.doi.org/10.3390/molecules15117985.

KHODDAMI, A., WILKES, M.A. and ROBERTS, T.H., 2013. Techniques for analysis of plant phenolic compounds. Molecules, vol. 18, no. 2, pp. 2328-2375. PMid:23429347. http://dx.doi. org/10.3390/molecules 18022328 .

KSOURI, R., KSOURI, W.M., JALLALI, I., DEBEZ, A., MAGNÉ, C., HIROKO, I. and ABDELLY, C., 2012. Medicinal halophytes: potent source of health promoting biomolecules with medical, nutraceutical and food applications. Critical Reviews in Biotechnology, vol. 32, no. 4, pp. 289-326. PMid:22129270. http://dx.doi.org/10.3109/07388551.2011.630647.

KSOURI, R., MEGDICHE, W., FALLEH, H., TRABELSI, N., BOULAABA, M., SMAOUI, A. and ABDELLY, C., 2008. Influence of biological, environmental and technical factors on phenolic content and antioxidant activities of Tunisian halophytes. Comptes Rendus Biologies, vol. 331, no. 11, pp. 865-873. PMid:18940702. http://dx.doi.org/10.1016/j.crvi.2008.07.024.

KUMAR, N. and PRUTHI, V., 2014. Potential applications of ferulic acid from natural sources. Biotechnology Reports, vol. 4, pp. 86-93. http://dx.doi.org/10.1016/j.btre.2014.09.002

MEGÍAS, C., PASTOR-CAVADA, E., TORRES-FUENTES, C., GIRÓN-CALLE, J., ALAIZ, M., JUAN, R., PASTOR, J. and VIOQUE, J., 2009. Chelating, antioxidant and antiproliferative activity of Vicia sativa polyphenol extracts. European Food Research and Technology, vol. 230, no. 2, pp. 353-359. http:// dx.doi.org/10.1007/s00217-009-1178-x.

MORENO, S., SCHEYER, T., ROMANO, C. and VOJNOV, A., 2006. Antioxidant and antimicrobial activities of rosemary extracts linked to their polyphenol composition. Free Radical Research, vol. 40, no. 2, pp. 223-231. PMid:16390832. http:// dx.doi.org/10.1080/10715760500473834.

NACZK, M. and SHAHIDI, F., 2004. Extraction and analysis of phenolics in food. Journal of Chromatography. A, vol. 1054, no. 1-2, pp. 95-111. PMid:15553136. http://dx.doi.org/10.1016/ S0021-9673(04)01409-8.

PETERSEN, M. and SIMMONDS, M.S.J., 2003. Rosmarinic acid. Phytochemistry, vol. 62, no. 2, pp. 121-125. PMid:12482446. http://dx.doi.org/10.1016/S0031-9422(02)00513-7. 
RASKIN, I., 1992. Role of salicylic acid in plants. Annual Review of Plant Physiology and Plant Molecular Biology, vol. 43, no. 1, pp. 439-463. http://dx.doi.org/10.1146/annurev.pp.43.060192.002255.

RE, R., PELLEGRINI, N., PROTEGGENTE, A., PANNALA, A., YANG, M. and RICE-EVANS, C., 1999. Antioxidant activity applying an improved ABTS radical cation decolorization assay. Free Radical Biology \& Medicine, vol. 26, no. 9-10, pp. 1231-1237. PMid:10381194. http://dx.doi.org/10.1016/S0891-5849(98)00315-3.

REDZIC, S., 2006. Wild Edible Plants and Their Traditional Use in the Human Nutrition in Bosnia-Herzegovina. Ecology of Food and Nutrition, vol. 45, no. 3, pp. 189-232. http://dx.doi. org/10.1080/03670240600648963.

RODRIGUES, M.J., GANGADHAR, K.N., VIZETTO-DUARTE, C., WUBSHET, S.G., NYBERG, N.T., BARREIRA, L., VARELA, J. and CUSTÓDIO, L., 2014. Maritime halophyte species from southern Portugal as sources of bioactive molecules. Marine Drugs, vol. 12, no. 4, pp. 2228-2244. PMid:24727393. http:// dx.doi.org/10.3390/md12042228.

RODRIGUES, M.J., SOSZYNSKI, A., MARTINS, A., RAUTER, A.P., NENG, N.R., NOGUEIRA, J.M.F., VARELA, J., BARREIRA, L. and CUSTÓDIO, L., 2015. Unravelling the antioxidant potential and the phenolic composition of different anatomical organs of the marine halophyte Limonium algarvense. Industrial Crops and Products, vol. 77, pp. 315-322. http://dx.doi.org/10.1016/j. indcrop.2015.08.061.

SEAL, A.N., PRATLEY, J.E., HAIG, T. and AN, M., 2004. Identification and quantitation of compounds in a series of allelopathic and non-allelopathic rice root exudates. Journal of Chemical Ecology, vol. 30, no. 8, pp. 1647-1662. PMid:15537165. http://dx.doi.org/10.1023/B:JOEC.0000042074.96036.14.

SINGH, P.K. and GAUTAM, S., 2013. Role of salicylic acid on physiological and biochemical mechanism of salinity stress tolerance in plants. Acta Physiologiae Plantarum, vol. 35, no. 8, pp. 2345-2353. http://dx.doi.org/10.1007/s11738-013-1279-9.

TAKAO, L.K., IMATOMI, M. and GUALTIERI, S.C.J., 2015. Antioxidant activity and phenolic content of leaf infusions of Myrtaceae species from Cerrado (Brazilian Savanna). Brazilian Journal of Biology = Revista Brasileira de Biologia, vol. 75, no. 4, pp. 948-952. PMid:26675912. http://dx.doi.org/10.1590/15196984.03314 .

TAMURA, Y. and NISHIBE, S., 2002. Changes in the concentrations of bioactive compounds in plantain leaves. Journal of Agricultural and Food Chemistry, vol. 50, no. 9, pp. 2514-2518. PMid:11958614. http://dx.doi.org/10.1021/jf011490x.

TAWAHA, K., ALALI, F.Q., GHARAIBEH, M., MOHAMMAD, M. and EL-ELIMAT, T., 2007. Antioxidant activity and total phenolic content of selected Jordanian plant species. Food Chemistry, vol. 104, no. 4, pp. 1372-1378. http://dx.doi.org/10.1016/j. foodchem.2007.01.064.

US DEPARTMENT OF AGRICULTURE - USDA. Agricultural Research Service. Nutrient Data Laboratory, 2015 [viewed 5 January 2016]. USDA National Nutrient Database for Standard Reference, Release 28. Version Current: September 2015 [online]. Washington. Available from: http://www.ars.usda.gov/ba/bhnrc/ndl

VAUZOUR, D., CORONA, G. and SPENCER, J.P.E., 2010. Caffeic acid, tyrosol and p-coumaric acid are potent inhibitors of 5-S-cysteinyl-dopamine induced neurotoxicity. Archives of Biochemistry and Biophysics, vol. 501, no. 1, pp. 106-111. PMid:20361927. http://dx.doi.org/10.1016/j.abb.2010.03.016.

VELIOGLU, Y.S., MAZZA, G., GAO, L. and OOMAH, B.D., 1998. Antioxidant activity and total phenolics in selected fruits, vegetables and grain products. Journal of Agricultural and Food Chemistry, vol. 46, no. 10, pp. 4113-4117. http://dx.doi. org/10.1021/jf9801973.

VUUREN, S.F.V., 2008. Antimicrobial activity of South African medicinal plants. Journal of Ethnopharmacology, vol. 119, no. 3, pp. 462-472. PMid:18582553. http://dx.doi.org/10.1016/j. jep.2008.05.038.

WORLD HEALTH ORGANIZATION - WHO. Food and Agricultural Organization of the United Nations - FAO, 1973. Energy and protein requirements: report of a joint FAO/WHO Ad Hoc expert committee. Geneva. 118 p. FAO Nutrition Meetings Report Series, no. 52; World Health Organization Technical Report Series, no. 522.

WU, G., 2009. Amino acids: metabolism, functions, and nutrition. Amino Acids, vol. 37, no. 1, pp. 1-17. PMid:19301095. http:// dx.doi.org/10.1007/s00726-009-0269-0.

ZOU, J.Y., CHANG, S.K.C., GU, Y. and QIAN, S.Y., 2011. Antioxidant activity and phenolic compositions of lentil (Lens culinaris var. Morton) extract and its fractions. Journal of Agricultural and Food Chemistry, vol. 59, no. 6, pp. 2268-2276. PMid:21332205. http://dx.doi.org/10.1021/jf104640k. 